\title{
Glial Cell Line-Derived Neurotrophic Factor Family Receptors Are Abnormally Expressed in Aganglionic Bowel of a Subpopulation of Patients with Hirschsprung's Disease
}

\author{
Vincent Chi Hang Lui, Eileen Teresa Samy, Mai Har Sham, Lois M. Mulligan, and \\ Paul Kwong Hang Tam
}

Division of Paediatric Surgery (VCHL, ETS, PKHT), Department of Surgery, University of Hong Kong Medical Centre, Queen Mary Hospital, and Department of Biochemistry (MHS), University of Hong Kong, Hong Kong SAR, China; and Department of Pathology and Paediatrics (LMM), Queen's University, Kingston, Ontario, Canada

\begin{abstract}
SUMMARY: Hirschsprung's disease (HSCR), a congenital disease, is characterized by the absence of ganglion cells in the ganglion plexuses of the caudal most gut. In the aganglionic colon, the plexus remnants are replaced by aggregates of glial cells and hypertrophied nerve fibers. Signaling of glial cell line-derived neurotrophic factor (GDNF)-GFRAs-receptor tyrosine kinase (RET) is crucial for the development and maintenance of ganglion cells. Mutations of genes such as GDNF and RET lead to the perturbation of this signaling pathway, which causes HSCR. To understand the role of GFRAs in ganglion cells and the pathogenesis of HSCR, we intended to determine the specific cell lineages in the enteric nervous system that normally express GFRAs but are affected in HSCR. We studied colon biopsy specimens from 13 patients with HSCR (aged 1 day to 38 months) and 6 age-matched patients without HSCR as normal controls. RT-PCR, in situ hybridization, and immunohistochemistry were performed to examine the expression and cellular distributions of GFRAs in resected bowel segments of normal infants and those with HSCR. In normal infants and normoganglionic colon of patients with HSCR, the expression of GFRA1 was restricted to the glial cells and neurones of the ganglion plexuses. GFRAs expression was found to be markedly reduced in the aganglionic colons of 3 infants with HSCR but was unaffected in the aganglionic colons of 10 other infants with HSCR. Residual GFRA expression was restricted to enteric glial cells in the plexus remnants of the aganglionic colons. Hypertrophied nerve fibers were not found to express GFRA1. We provide the first evidence that abnormal expression of GFRAs in the enteric nervous system may be involved in the pathogenesis of HSCR in a subpopulation of patients. (Lab Invest 2002, 82:703-711).
\end{abstract}

G lial cell line-derived neurotrophic factor (GDNF) family ligands (GFLs) are distant members of the tumor growth factor- $\beta$ superfamily. They are crucial for the development and survival of neurones in the central, peripheral, and enteric nervous systems (ENS) (Airaksinen et al, 1999; Takahashi, 2001). Four GFLs have been identified: GDNF; neurturin (NTRN); artemin; and persephin. The GFLs signal through a multicomponent receptor complex. This complex consists of a glycosylphosphatidylinositol-linked membrane bound coreceptor GFRalpha (GFRA1-GFRA4) and receptor tyrosine kinases (RETs) on the cell membrane. Each GFL has a preferred GFRA coreceptor to which it binds with the highest affinity and to activate RET.

\section{DOI: 10.1097/01.LAB.0000017364.13014.AE}

Received November 19, 2001.

This work was partially supported by the University of Hong Kong CRCG seed funding 1999-2000 (10203029/14287/21700/302/01) and the Hong Kong RGC CERG 2000-2001 (HKU 7358/00M).

Address reprint requests to: Dr. Paul Kwong Hang Tam, Division of Paediatric Surgery, Department of Surgery, University of Hong Kong Medical Centre, Queen Mary Hospital, Pokfulam, Hong Kong SAR, China.E-mail:paultam@hkucc.hku.hk
The highest affinity combinations are GDNF-GFRA1 (Jing et al, 1996; Treanor et al, 1996), NTRN-GFRA2 (Baloh et al, 1997; Buj-Bello et al, 1997; Jing et al, 1996, 1997; Klein et al, 1997; Sanicola et al, 1997; Suvanto et al, 1997; Treanor et al, 1996), arteminGFRA3 (Baloh et al, 1998), and persephin-GFRA4 (Enokido et al, 1998; Masure et al, 2000). The binding of GFL to its GFRA induces the formation of a complex between GFL-GFRA and RET, resulting in dimerization of RET and activation of the RET kinase domain. When this ligand receptor complex is formed between molecules on the same cell, it is termed cis signaling. However, GFRA1 can function in a non-cellautonomous manner by capturing and concentrating diffusible GDNF from the extracellular milieu and presenting bound GDNF to the surrounding RETexpressing cells in a trans manner (trans signaling). Recently, trans signaling between GDNF, GFRA1, and RET were demonstrated in rat gut (Worley et al, 2000) and in rat neuronal cell lines (Paratcha et al, 2001). In early embryonic rat gut (embryonic Day 13.5), the GFRA1 hybridization signal was observed in the gut mesenchyme and was not restricted to regions containing RET-immunopositive cells. In later develop- 
ment, GFRA1-positive signals are restricted to myenteric regions where RET immunopositive cells are colocalized. It was found that the soluble form of GFRA1 released from the cells of gut mesenchyme could potentiate the induction effect of GDNF on the proliferation and survival of neurones (Worley et al, 2000). Alternatively, trans signaling that involves the interactions between GDNFGFRA1 and RET on two different cells in intimate contact has been suggested in the adult rat central nervous system (Trupp et al, 1997; Yu et al, 1998).

Mutation screening of GFRA genes in patients with Hirschsprung's disease (HSCR) failed to identify any mutation. This suggests that mutations of GFRA genes are not common etiologic events in HSCR (Angrist et al, 1998; Myers et al, 1999; Onochie et al, 2000; Vanhorne et al, 2001). Critical roles of GFRAs in the development of the ENS were substantiated by gene targeting experiments in mice. Mice deficient for GFRA1 demonstrated lack of enteric neurones and kidney agenesis (Cacalano et al, 1998; Enomoto et al, 1998). The defects of ENS and kidney in GFRA1deficient mice are similar to those of both GDNF- and RET-deficient mice (Moore et al, 1996; Pichel et al, 1996; Sanchez et al, 1996; Schuchardt et al, 1994). This suggests stringent pairing between GDNF, GFRA1, and RET in ENS and kidney development. Ganglion cells were completely absent in the intestine distal to the stomach in mice that are deficient for GFRA1, GDNF, or RET. ENS defects were less severe in GFRA2-deficient mice, and only the parasympathetic cholinergic innervation in the small intestine was affected (Rossi et al, 1999).

The relative importance of cis and trans GDNF signaling in human ENS development is not yet known. To examine the cis and trans GDNF signaling in human ENS development, it is crucial to determine the cellular distribution of GFRAs and RET in the ENS. Previous in situ hybridization experiments have shown colocalization of transcripts of GFRA1 and GFRA2 with RET in 25-week-old fetal and neonatal colon (Wartiovaara et al, 1998). However, cellular distributions of GFRAs and RET mRNAs are not known. To understand the functions of cis and trans GDNF signaling mechanisms in human ENS development and associated neurocristopathies, we determined the specific cell lineages that normally express GFRAs but are affected in HSCR colons in the ENS of infants. The expression of GFRA1 in normal infants and normoganglionic colon of HSCR patients was shown to be restricted to RET-negative glial cells and RET-positive neurones of the ganglion plexuses. GFRAs expression was found to be markedly reduced in the aganglionic colon of some infants with HSCR. Abnormal interaction and signaling between glial cells and neurones may be involved in the pathogenesis of HSCR.

\section{Results}

\section{Glial Cells and Neurones of Ganglion Plexuses Express GFRA1}

The ganglion plexuses in gut are composed of two morphologically distinct cell types: glial cells and neurones. The nuclei of glial cells are smaller and slightly elongated, whereas the nuclei of neurones are bigger and round. Glial cells and the nerve fascicle within the myenteric and submucosal plexuses were stained positively with anti-S100 antibody (Fig. 1, A and C). Neurones were not stained with anti-S100 antibody but were immunoreactive for anti-RET antibody (Fig. 1, A and C, and data not shown). The distribution of GFRA1 transcript in colons of normal infants was determined by in situ hybridization. GFRA1 hybridization signals overlapped with both glial cells and neurones in myenteric and submucosal plexuses (Fig. 1, A to D). Our immunohistochemical studies and in situ hybridization analysis on adjacent sections indicated that glial cells and neurones in the myenteric and submucosal plexuses express GFRA1. No hybridization signal of GFRA1 was found in the extrinsic nerves of the serosa (not shown). No specific

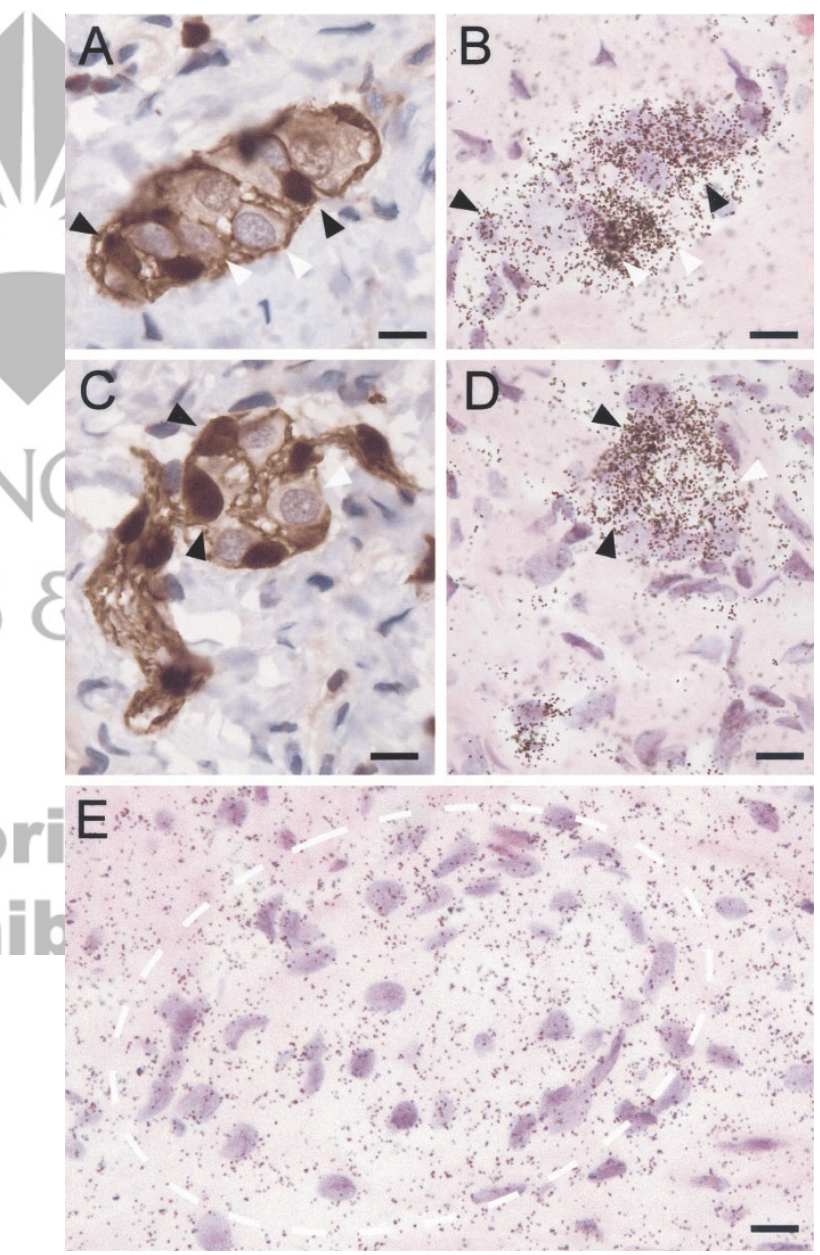

Figure 1.

In situ hybridization analysis of GFRA1 expression in normal infant colon. Adjacent sections were immunostained with anti-S100 antibody ( $A$ and $C$ ) or hybridized with GFRA1 riboprobe (B and D). Glial cells in the ganglion plexuses are smaller with elongated nuclei (black arrowheads) and were S100 immunopositive. Neuronal cells are bigger with round nuclei (white arrowheads) and were not immunostained with anti-S100 antibody. Transcripts of GFRA1 were localized to glial (black arrowheads) and neuronal cells (white arrowheads) of myenteric plexus (B) and submucosal plexus (D). Sense riboprobe of GFRA1 showed no specific hybridization (E). Photographs of the hybridized sections were taken under bright field illumination. Scale bars represent $10 \mu \mathrm{m}$. 
hybridization signal was observed on sections when sense riboprobes were used in the in situ hybridization (Fig. 1E).

To further examine the cellular distribution of the GFRA1 coreceptor in ganglion plexuses, we performed immunohistochemistry using antibodies against the glial cell marker S100, the neurone marker RET, and the GFRA1 coreceptor protein on colon sections of normal controls. Anti-S100 antibody positively stained the glial cells and nerve fascicles in the plexuses (Fig. 2, A and D). Anti-RET antibody positively stained the neurones and nerve fascicles in the plexuses (Fig. 2, B and E). Immunostaining of GFRA1 overlapped with $\mathrm{S} 100$ immunopositive glial cells and RET immunopositive neurones in the plexus. In addition, the nerve fascicles within the plexuses were also positively stained for GFRA1 (Fig. 2, C and F). Our immunostaining result confirmed the in situ hybridization data and indicated that the GFRA1 coreceptor was present on both glial cells and neurones of the myenteric and submucosal plexuses.

\section{Cellular Distribution of GFRAs in HSCR Colon}

Semiquantitative RT-PCR analysis was performed to investigate the expression of GFRA1, GFRA2, and GFRA3 in various segments of the resected colon of infants with HSCR (Table 1). Comparable levels of GFRA1, GFRA2, and GFRA3 were detected in the aganglionic, hypoganglionic, and normoganglionic coIon in 10 infants with HSCR (Fig. 3A and not shown). In the other three infants with HSCR, the levels of GFRA1, GFRA2, and GFRA3 were markedly lower in the aganglionic colon compared with the normoganglionic colon of the same patient (Fig. 3B). Intensities of PCR bands were quantified, and the relative ex-

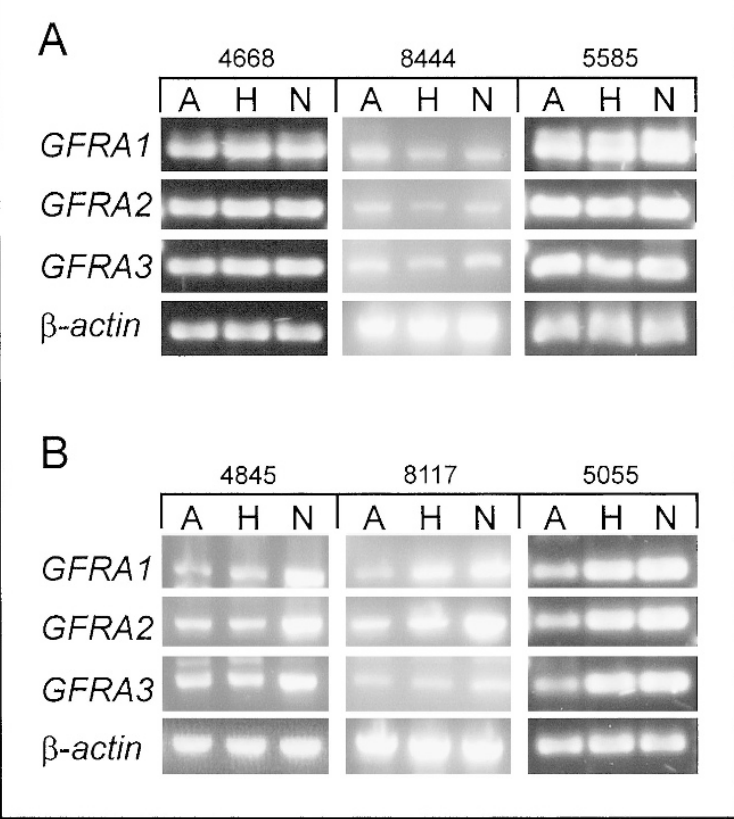

Figure 3.

Semiquantitative RT-PCR analysis of GFRA expression in Hirschsprung's disease (HSCR) colon. Expression of GFRAs and $\beta$-actin in aganglionic (A), hypoganglionic $(H)$, and normoganglionic (N) segments of resected colon were analyzed. A, Representative RT-PCR results from patients with HSCR showed no reduction of GFRA expression in aganglionic colon. B, RT-PCR results of three patients with HSCR showed reduced expression of GFRAs in their aganglionic colons. Identification numbers of the patients are shown above the lanes.

pression levels of GFRA1, GFRA2, and GFRA3 to $\beta$-actin were determined. Relative expressions of GFRA1, GFRA2, and GFRA3 were not significantly different between various segments of colons in 10

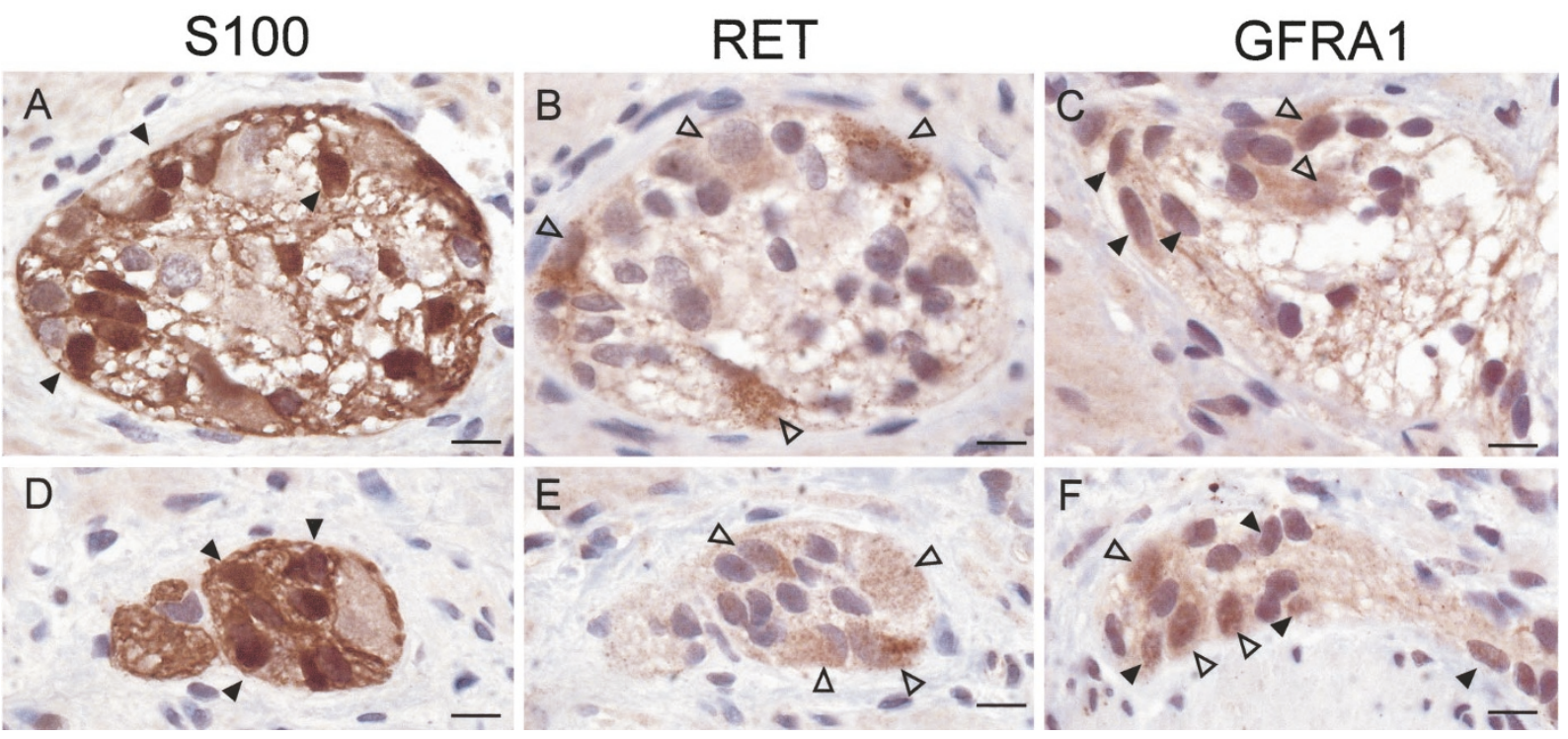

Figure 2.

Immunolocalization of GFRA1 coreceptor protein to ganglion plexuses. Myenteric plexus (A to C) and submucosal plexus (D to F) were immunostained for S100 (A and D), RET (B and E), and GFRA1 ( $C$ and F). Glial cells (black arrowheads) were immunoreactive for S100 ( $\mathrm{A}$ and D). Neurones (unfilled arrowheads) were immunoreactive for RET (B and E). Both neurones (unfilled arrowheads) and glial cells (filled arrowheads) were positively immunostained with anti-GFRA1 antibody (C and F). Scale bars represent $10 \mu \mathrm{m}$. 
Table 1. Primers, PCR Conditions for GFRAs and $\beta$-actin

\begin{tabular}{|c|c|c|c|}
\hline Gene & Primers & Annealing temperature $\left({ }^{\circ} \mathrm{C}\right)$ & RT-PCR product (bp) \\
\hline \multirow[t]{2}{*}{ GFRA1 } & F: 5'AGGGAAATGATCTGCTGGAGGA3' & 60 & 495 \\
\hline & R: 5'CTCTGGCTGGCAGTTGGTAAAA3' & & \\
\hline \multirow[t]{2}{*}{ GFRA2 } & F: 5'AGGCCCTGCGCCAGTTCTTCGA3' & 60 & 477 \\
\hline & R: 5'ACGTTCACGTCCGTGCCGTTGC3' & & \\
\hline \multirow[t]{2}{*}{ GFRA3 } & F: 5'CTGCACCTCTAGCATAAGCACC3' & 65 & 458 \\
\hline & 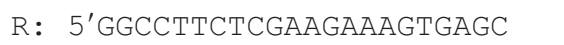 & & \\
\hline \multirow[t]{2}{*}{$\beta$-actin } & $\mathrm{F}:$ 5'CCTCGCCTTTGCCGATCC3' & 60 & 626 \\
\hline & R: 5'GGATCTTCATGAGGTAGTCAGTC3' & & \\
\hline
\end{tabular}

$\mathrm{F}$, forward primer; $\mathrm{R}$, reverse primer.

patients with HSCR (Table 2). Relative expressions of GFRA1, GFRA2, and GFRA3 were consistently lower in the aganglionic and hypoganglionic colon than the normoganglionic colon in three patients with HSCR. However, only the difference in relative expression of GFRA1 between aganglionic and normoganglionic colons reached statistical significance $(p=0.04$; Table 2). No amplified product was obtained in negative controls in which reverse transcriptase was omitted (not shown). This indicates that the amplicons observed in our samples were derived from RNA. Clinical features including gender, age, length of aganglionosis, mode of inheritance of the disease, and associated clinical complications were carefully analyzed and compared in the 13 patients with HSCR (Table 3). We were unable to find an obvious association of the down-regulation of GFRAs expression with any distinguishable clinical features in the three patients who showed abnormal GFRAs expression. However, all the patients recruited in the present study suffer from sporadic short-segment disease, and the patient number was too few for a definite association analysis. Further study including a wider spectrum of patients with short-segment HSCR, long-segment HSCR, or familial HSCR is required to clarify the association of the down-regulation of GFRA expression with the variation in clinical features of HSCR disease.

To determine whether the expression of GFRA1 is down-regulated in the ganglion plexuses of aganglionic colon and whether GFRA1 was ectopically expressed in aganglionic colon, in situ hybridization was performed on the resected colons of the HSCR specimens that showed reduced GFRA1 expression by RT-PCR analysis. GFRA1 hybridization signal was readily detectable in the ganglion plexuses of the normoganglionic colon but was not detected in the aganglionic colon (Fig. 4, A to D). In situ hybridization was also performed on the HSCR specimens that did not show reduced expression of GFRA1 gene by RT-PCR analysis. Transcripts of GFRA1 were detectable in the ganglion plexuses of normoganglionic colon and in aganglionic colon (Fig. 4, E to H). No signal was found in the hypertrophied nerves in the aganglionic colon (Fig. 4, I to L).

It is known that hypertrophied nerves are present in the hypoganglionic colon. To ascertain that the specimen we analyzed was indeed aganglionic, immunohistochemical analysis was performed on adjacent sections of the specimens using antibodies specific for glial cells and neurones. In aganglionic colon, where no neurone was found in the ganglion plexus, the plexus remnants consisted of hypertrophied nerve trunks and glial cells. As shown in Figure 4, the plexus remnant was positively stained for $\mathrm{S} 100$ but not for RET. Anti-S100 antibody stained the glial cells as well as the fiber-like structure in the plexus remnant. The glial cells and the fiber-like structure in the plexus remnant were also immunopositive for GFRA1. The immunostaining result indicated that the plexus remnants in the aganglionic colon were devoid of neurone and contained only glial cells that are immunopositive for GFRA1 and S100. This confirmed that the speci-

Table 2. Statistical Analysis of Expression of GFRA

\begin{tabular}{|c|c|c|c|}
\hline & $\begin{array}{l}\text { GFRA1/ } \beta \text {-actin } \\
(\text { mean } \pm \text { SEM) }\end{array}$ & $\begin{array}{l}\text { GFRA2/ } \beta \text {-actin } \\
(\text { mean } \pm \text { SEM })\end{array}$ & $\begin{array}{c}\text { GFRA3/ } \beta \text {-actin } \\
\text { (mean } \pm \text { SEM) }\end{array}$ \\
\hline \multicolumn{4}{|l|}{ HD (Group I, $n=8$ ) } \\
\hline Normoganglionic segment & $1.15 \pm 0.29$ & $0.82 \pm 0.16$ & $1.02 \pm 0.18$ \\
\hline Hypoganglionic segment & $1.22 \pm 0.24(p=0.77)^{a}$ & $1.17 \pm 0.24(p=0.93)^{a}$ & $0.93 \pm 0.18(p=0.80)^{a}$ \\
\hline Aganglionic segment & $1.13 \pm 0.21(p=0.95)^{b}$ & $1.20 \pm 0.23(p=0.19)^{b}$ & $0.87 \pm 0.10(p=0.48)^{b}$ \\
\hline \multicolumn{4}{|l|}{ HD (Group II, $n=3$ ) } \\
\hline Normoganglionic segment & $1.05 \pm 0.23$ & $1.16 \pm 0.33$ & $0.84 \pm 0.34$ \\
\hline Hypoganglionic segment & $0.70 \pm 0.31(p=0.23)^{a}$ & $0.80 \pm 0.32(p=0.38)^{a}$ & $0.55 \pm 0.34(p=0.50)^{a}$ \\
\hline Aganglionic segment & $0.23 \pm 0.13(p=0.04)^{b}$ & $0.45 \pm 0.15(p=0.12)^{b}$ & $0.29 \pm 0.1(p=0.19)^{b}$ \\
\hline
\end{tabular}

Unpaired $t$ test was performed to evaluate the significance of the difference of the relative expression levels of GFRA1, GFRA2, and GFRA3 in various segments of $\mathrm{HD}$ patients. The two-tailed $p$ values of the comparison of the relative expression levels of GFRA1, GFRA2, and GFRA3 in the hypoganglionic segments with normoganglionic segments ${ }^{a}$ or aganglionic segments with normoganglionic segments ${ }^{b}$ of patients with HD are shown ( $p<0.05$ is considered to be significant). 
Table 3. Clinical Features of the Patients with HSCR

\begin{tabular}{ccccc}
\hline $\begin{array}{c}\text { Case } \\
\text { no. }\end{array}$ & Gender & Age & Diagnosis & $\begin{array}{c}\text { Familial } \\
\text { or } \\
\text { sporadic }\end{array}$ \\
\hline 6297 & M & 38 mo & Rectal HSCR & S \\
7131 & M & 14 mo & Short HSCR & S \\
4554 & M & 4 days & Short HSCR & S \\
4668 & M & 8 days & Short HSCR & S \\
$4845^{\star}$ & M & 24 days & Short HSCR & S \\
5585 & M & 30 days & Short HSCR & S \\
$5055^{*}$ & M & 10 mo & Short HSCR & S \\
B211 & M & 2.5 mo & Short HSCR & S \\
B241 & F & 2 mo & Short HSCR & S \\
$8117^{*}$ & F & 1 day & Short HSCR, enterocolitis & S \\
4421 & M & 18 days & Short HSCR, enterocolitis & S \\
8444 & M & 24 days & Short HSCR, enterocolitis & S \\
B100 & F & 2.6 mo & Short HSCR, enterocolitis & S \\
\hline
\end{tabular}

$M$, male; $F$, female; $S$, sporadic.

Patients who display down-regulation of GFRAs in aganglionic colon are indicated with *

men we analyzed was obtained from aganglionic colon. Immunostaining for S100, RET, and GFRA1 was performed on colon biopsy specimens of all 10 patients with HSCR who did not show downregulation of GFRAs in the aganglionic colon. The plexus remnants in the aganglionic colon of these patients were immunopositive for $\mathrm{S} 100$ and GFRA1 but negative for RET (not shown).

\section{Discussion}

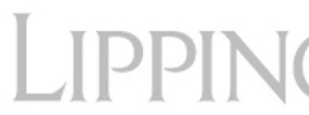

GFLs bind to GFRA and this GFL-GFRA complex then binds to RET, leading to the activation of the kinase activity of RET and trans-membrane GFL-mediated signal transduction. RET is only expressed by neurones, indicating that neurones are the target cell type of GFL in the ENS. Previous study has shown that transcripts of GFRA1 and GFRA2 were restricted to the myenteric and submucosal plexuses (Wartiovaara et al, 1998). However, the cellular distribution of GFRAs has not been determined.

We have determined the cellular distribution of GFRA1 in the colon of normal infants and those with HSCR. We found that both glial cells and neurones in the myenteric and submucosal plexuses of the colons of normal infants express GFRA1. The presence of GFRA1 coreceptors on glial cells, neurones, and nerve fascicles in the myenteric and submucosal plexuses was confirmed with immunohistochemistry using a specific antibody against GFRA1.

GDNF signaling via GFRAs and RET can be accomplished through both cis and trans manners (Paratcha et al, 2001; Worley et al, 2000). In line with the trans GDNF signaling, we show that GFRA1 are present on both glial cells and neurones that are in close proximity to each other in ganglion plexuses. The trans GDNF-mediated response is weaker compared with the cell surface GFRA1 (Paratcha et al, 2001; Worley et al, 2000). The maximum response was only seen when both the cell surface and released forms of GFRA1 were present simultaneously, suggesting that cis and trans GDNF signaling function synergistically. Functioning synergistically with the cis signaling, trans GFL signaling may modulate the trophic and survival functions of GFLs to neurones, which are essential for the maintenance of ENS in the developing and postnatal gut. Expression of GFRA1 in glial cells has also been shown in the anterior horn of the spinal cord, in addition to its expression in motor neurones (Mitsuma et al, 1999). This suggests that trans GFL signaling is required in nervous systems other than ENS.

Two distinct patterns of expression of GFRAs were noted in the patients with HSCR in the present study. Expression of GFRA1, GFRA2, and GFRA3 was unaffected in aganglionic colon in 10 patients. The residual GFRA1 hybridization signals were restricted to the glial cells in the plexus remnants in the aganglionic colon. In aganglionic colon, the plexus remnants consisted of hypertrophic nerve trunks and glial cells. The hypertrophied nerve trunks consist of cholinergic nerve fibers that have been shown to be extrinsic parasympathetic nerve fibers of sacral origin (Kobayashi et al, 1994; Robertson et al, 1997; Tam and Boyd, 1990). Our result that shows that both the extrinsic parasympathetic nerves and the abnormal hypertrophied nerves are negative for GFRA1 is in line with the suggestion that hypertrophied nerve trunks are derived from the extrinsic parasympathetic nerve fibers. Therefore, it is likely that the GFRA1 and S100 immunoreactive glial cells in the plexus remnants in aganglionic colon are enteric glial cells. In the other three patients, weaker expression of GFRA1, GFRA2, and GFRA3 was detected in aganglionic colon. In situ hybridization analysis confirmed that GFRA1 expression was specifically down-regulated in the myenteric and submucosal plexuses in aganglionic colon in this group of patients.

The etiology of HSCR is complex and remains to be fully elucidated. In line with the complex nature of the etiology of HSCR, mutations of genes including RET, EDN3 and END3 receptor EDNRB, GDNF, NTRN account for the etiology of $30 \%$ to $50 \%$ of reported HSCR cases (Martucciello et al, 2000; Parisi and Kapur, 2000). Screening of GFRA in patients with HSCR has failed to identify any mutation. This suggests that mutations of GFRA are not a common etiologic event in HSCR (Angrist et al, 1998; Myers et al, 1999; Onochie et al, 2000; Vanhorne et al, 2001). Germline mutations of GDNF are not sufficient to cause HSCR but might interact with other HSCR susceptibility loci including RET and modulate the disease phenotype. This implies that optimal GDNF signaling is crucial for the functioning of the ENS (Angrist et al, 1996; Salomon et al, 1996). RET mutations reported by investigators, the most frequently mutated gene associated with HSCR, accounted for $50 \%$ and $15 \%$ to $20 \%$ of familial and sporadic cases of HSCR, respectively (Fewtrell et al, 1994; Goyal and Hirano, 1996; Lyonnet et al, 1993; Sancandi et al, 2000; Seri et al, 1997; Yin et al, 1994) further confirmed that signaling through RET is crucial for ENS 

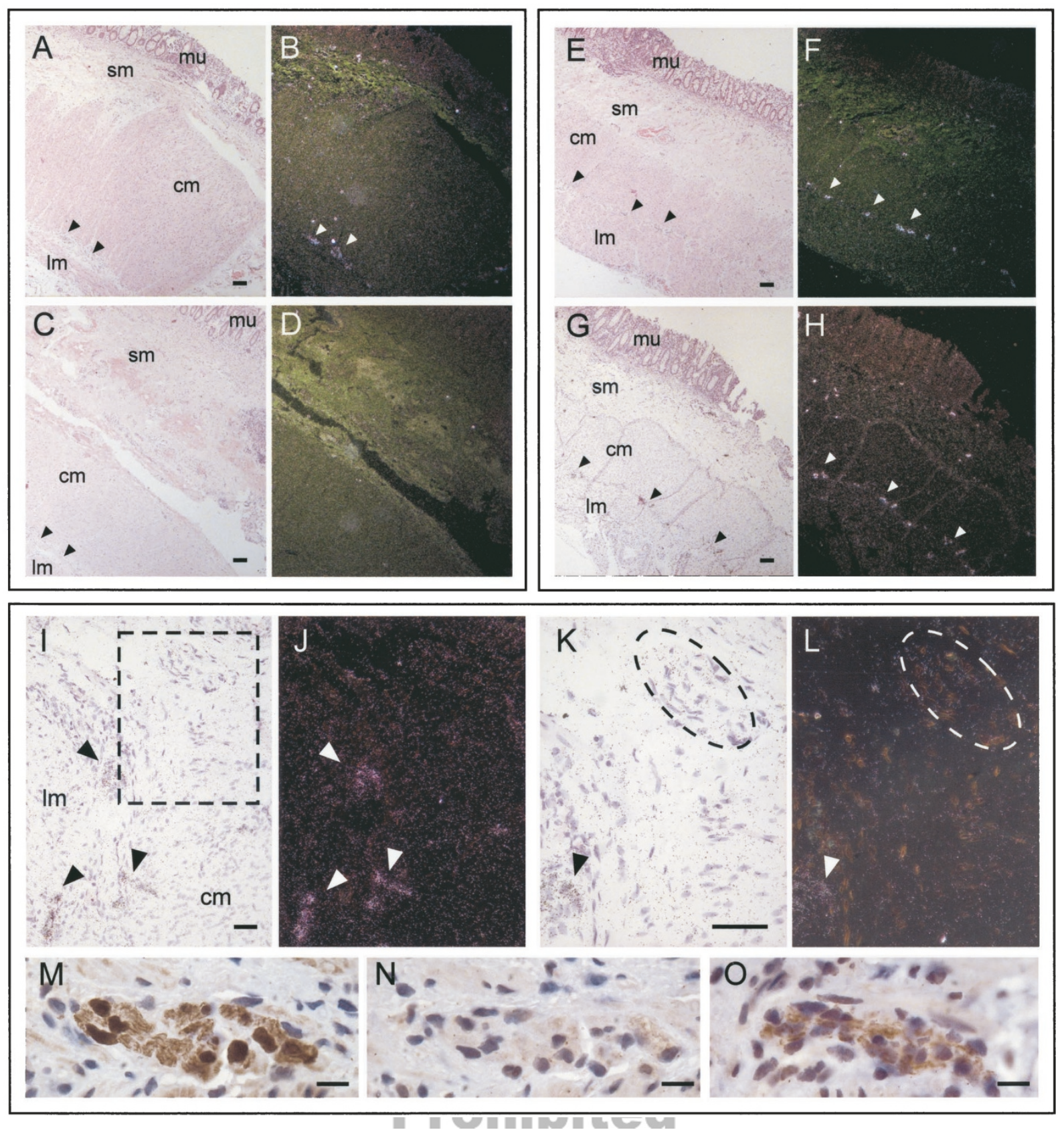

Figure 4.

In situ hybridization and immunohistochemical analysis of HSCR colon. Distribution of GFRA1 transcripts in normoganglionic colon (A, B, E, and F) and in aganglionic colon (C, D, and G to L) was analyzed with in situ hybridization. In patient 8117, GFRA1 transcripts were localized in the ganglion plexus (black arrowhead) of normoganglionic colon ( $A$ and $B$ ) but not in the myenteric region (black arrowhead) of aganglionic colon (C and D). In patient 8444, GFRA1 transcripts were localized to the ganglion plexus (black arrowhead) of normoganglionic colon ( $E$ and $F$ ) and in the plexus remnants (black arrowhead) in the myenteric region of the aganglionic colon ( $G$ to $L$ ). The region marked with a square in I was magnified as shown in $\mathrm{K}$ and $\mathrm{L}$. The hypertrophic nerve in the aganglionic colon was marked with ellipse ( $K$ and $L)$. Photographs of the hybridized sections were taken under bright field illumination ( $A, C, E, G, I, K)$ or dark field illumination (B, D, F, H, J, L). Localization of GFRA1 transcripts in dark field photographs was indicated with white arrowhead (B, D, F, H, J, L). Adjacent sections of the plexus remnant of aganglionic colon of patient 8444 were immunostained for S100 (M), RET (N), and GFRA1 (0). mu, mucosa; sm, submucosa; cm, circular muscle; Im, Iongitudinal muscle. Scale bars represent $50 \mu \mathrm{m}$ except in $\mathrm{M}, \mathrm{N}$, and 0 , where they represent $10 \mu \mathrm{m}$.

development. The lack of association between GFRA mutations and HSCR may underline the functional redundancy and cross-talks between these GFRA coreceptors and GFLs. In line with this, promiscuity in the ligand specificities of GFRAs with GDNF-GFRA2, NRTN-GFRA1, and artemin-GFRA1 known to other alternative combinations have already been demonstrated (Airaksinen et al, 1999).
To form the ENS, vagal and sacral neural crest cells migrate from the neural tube and colonize the developing gut in a rostral to caudal fashion (Gershon et al, 1993; Le Douarin and Teillet, 1973). During migration, neural crest cells undergo cell division to produce sufficient numbers of glial and neurone precursor cells to form the ENS. The postmitotic neurones extend axons to form a network of intestinal neurones (Costa 
and Brookes, 1994; Sang et al, 1997). The absence of glial cells and neurones in GDNF-, GFRA1-, or RETdeficient mice is probably a result of insufficient cell division and/or increased cell death of ENS precursors (Cacalano et al, 1998; Enomoto et al, 1998; Moore et al, 1996; Pichel et al, 1996; Sanchez et al, 1996; Schuchardt et al, 1994). However, NTRN- and GFRA2deficient mice develop specific defects on parasympathetic cholinergic neurones, which implies that NTRN signaling is the most important trophic factor for postmitotic neurones in developing ENS (Heuckeroth et al, 1999; Rossi et al, 1999). Data from these gene targeting experiments indicated that the GFLsGFRAs-RET signaling modulates the trophic and survival functions of GFLs to neurone precursor cells and postmitotic neurones. Therefore, the expression of GFRAs on glial cells and neurones must be precisely regulated to achieve optimal GFL-mediated signaling. Optimal GFL-mediated signaling is crucial for the survival and maintenance of neurones, and the normal functioning of ENS (Angrist et al, 1996; Salomon et al, 1996). Abnormal expression of GFRAs leads to suboptimal GFLs signaling in the ENS and may play a role in the etiology of HSCR. We provide the first evidence that abnormal expression of GFRAs may modulate disease phenotype in a subpopulation of patients with HSCR. HSCR is a polygenic disease caused by the additive subclinical effects of more than one gene. Our finding that abnormal expressions of GFRAs are detected only in a small subpopulation of patients with HSCR indeed complies with the complex polygenic nature of HSCR.

\section{Materials and Methods}

\section{Tissue Preparation for RNA Extraction and Section}

Resected colon specimens were collected from 13 patients with HSCR. Analysis of the rectal biopsy specimens of these patients revealed an absence of ganglion cells. Subsequent hematoxylin and eosin staining followed by acetylcholinesterase histochemical staining confirmed the diagnosis of short-segment aganglionosis in all 13 patients. Age- and sitematched specimens of the distal colon from nonHSCR patients (imperforated anus, $n=5$; rectal stricture, $n=1$ ) were included as controls. Control specimens were obtained from normal colon proximal to and well away from the diseased bowel; histologic analysis of control specimens confirmed no dysganglionosis. Full-thickness specimens from control colons as well as the aganglionic, hypoganglionic, and normoganglionic zones of HSCR bowel and control colons were used for RNA extraction using Trizol (Life Technologies, Rockville, Maryland). For tissue sections, the specimens were fixed in $4 \%$ paraformaldehyde/PBS ( $\mathrm{pH} 7.2)$ and embedded in paraffin. Sections (6 $\mu \mathrm{m}$ thickness) were prepared on microtome and mounted onto 3-aminopropyl-triethoxy-silanecoated slides (Sigma, St. Louis, Missouri), dried, and baked at $60^{\circ} \mathrm{C}$ for 1 hour.

\section{RT-PCR}

Total RNA $(2 \mu \mathrm{g})$ was used to synthesize the firststrand cDNA, using oligo dT and random hexamers (SuperScript Preamplification System; Life Technologies). Expression of GFRA1, GFRA2, GFRA3, and $\beta$-actin genes was analyzed using PCR. PCR was performed in $50 \mu$ l of standard buffer containing primers (0.2 $\mu \mathrm{M}$ each); $2 \mu \mathrm{l}$ of cDNA; $0.5 \mathrm{U}$ of AmpliTaq DNA polymerase (Life Technologies), $\mathrm{MgCl}_{2}$ (1.5 mm); and dNTP (0.2 mm). After the initial denaturation at $94^{\circ} \mathrm{C}$ for 3 minutes, PCR was performed for 25 cycles for $\beta$-actin, or 30 cycles for GFRA1, GFRA2, and GFRA3, as follows: 1 minute denaturation at $94^{\circ} \mathrm{C} ; 1$ minute at a primer specific annealing temperature; and 1 minute extension at $72^{\circ} \mathrm{C}$ for each cycle. A final extension for 10 minutes at $72^{\circ} \mathrm{C}$ was added. The number of PCR cycles was optimized for each primer set. Amplification was exponential up to 35 cycles for GFRA1, GFRA2, and GFRA3 primer sets. For $\beta$-actin, amplification was exponential up to 30 cycles. Amplifications were performed at 25-round cycles for $\beta$-actin, and 30-round cycles for GFRA1, GFRA2, and GFRA3. For control, PCRs were performed with the same set of RNAs but without the addition of reverse transcriptase to test for genomic contamination. Details of primers used for RT-PCR are shown in Table 1. RT-PCR of each sample was performed in duplicate. One-fifth of the PCR products was analyzed by electrophoresis in a 1.8\% agarose gel. Intensities of obtained PCR bands were determined using Scion Image software (Scion Corporation, Frederick, Maryland), and relative expression levels of GFRA1, GFRA2, and GFRA3 to $\beta$-actin, which were used as an external/control, were determined. Means and SEM of the relative expression of GFRA1, GFRA2, and GFRA3 were determined for each group. Unpaired $t$ test was performed to evaluate the significance of the differences between the relative expression levels of GFRA1, GFRA2, and GFRA3 in various segments of HSCR bowel. The two-tailed $p$ values of the comparison between the relative expression levels of GFRA1, GFRA2, and GFRA3 in various segments were determined. The difference was considered to be significant if the $p$ value was less than 0.05 .

\section{In Situ Hybridization}

To prepare riboprobes for GFRA1, an RT-PCR fragment of GFRA1 gene was cloned into pGEM-T Easy Vector (Promega, Madison, Wisconsin). Synthesis of riboprobes, hybridization, autoradiography, and histologic staining were performed as described previously (Wilkinson and Nieto, 1993). Slides were exposed in darkness at $4^{\circ} \mathrm{C}$ for 21 days. Photomicrographs were taken under dark field or bright field illumination using an Axioplan 2 microscope (Carl Zeiss, Oberkochen, Germany) fitted with a Sony digital camera.

\section{Immunohistochemistry}

Pretreatment of slides and antigen retrieval were performed as described previously (Lui et al, 2001). 
Sections were incubated with primary antibody (for S100: clone 4C4.9; NeoMarkers, Fremont, California; 1:100 dilution; for RET: anti-RET R5; Nagoya University, Nagoya, Japan; 1:100 dilution; for GFRA1, clone C-20; Dako, Carpinteria, California; 1:20 dilution) in PBS $(\mathrm{pH} 7.2)$ containing $0.1 \%$ Tween 20 and $10 \%$ horse serum at $4^{\circ} \mathrm{C}$ for 16 hours, followed by incubation with horseradish peroxidase-conjugated secondary antibody at $37^{\circ} \mathrm{C}$ for 1 hour. Immunoreactivity was visualized using a strepABComplex/HRP kit (Dako) and 3,3'-diaminobenzidine tetrahydrochloride (Sigma). Sections were counterstained with hematoxylin and then dehydrated, cleared in xylene, and mounted in DPX mountant (BDH, Poole, United Kingdom).

\section{References}

Airaksinen MS, Titievsky A, and Saarma M (1999). GDNF family neurotrophic factor signalling: Four masters, one servant? Mol Cell Neurosci 13:313-325.

Angrist M, Bolk S, Halushka M, Lapchak PA, and Chakravarti A (1996). Germline mutations in glial cell line-derived neurotrophic factor (GDNF) and RET in a Hirschsprung's disease patient. Nat Genet 14:341-344.

Angrist M, Jing S, Bolk S, Bentley K, Nallasamy S, Halushka M, Fox GM, and Chakravarti A (1998). Human GFRA1: Cloning, mapping, genomic structure, and evaluation as a candidate gene for Hirschsprung's disease susceptibility. Genomics 48:354-362.

Baloh RH, Gorodinsky A, Golden JP, Tansey MG, Keck CL, Popescu NC, Johnson EMJ, and Milbrandt J (1998). GFRalpha3 is an orphan member of the GDNF/neurturin/persephin receptor family. Proc Natl Acad Sci USA 95:5801-5806.

Baloh RH, Tansey MG, Golden JP, Creedon DJ, Heuckeroth RO, Keck CL, Zimonjic DB, Popescu NC, Johnson EMJ, and Milbrandt J (1997). TrnR2, a novel receptor that mediates neurturin and GDNF signalling through Ret. Neuron 18:793802

Buj-Bello A, Adu J, Pinon LG, Horton A, Thompson J, Rosenthal A, Chinchetru M, Buchman VL, and Davies AM (1997). Neurturin responsiveness requires a GPI-linked receptor and the Ret receptor tyrosine kinase. Nature 387:721 724.

Cacalano G, Farinas I, Wang LC, Hagler K, Forgie A, Moore M, Armanini M, Phillips H, Ryan AM, Reichardt LF, Hynes M, Davies A, and Rosenthal A (1998). GFRalpha1 is an essential receptor component for GDNF in the developing nervous system and kidney. Neuron 21:53-62.

Costa M and Brookes SJ (1994). The enteric nervous system. Am J Gastroenterol 89:S129-S137.

Enokido Y, de Sauvage F, Hongo JA, Ninkina N, Rosenthal A, Buchman VL, and Davies AM (1998). GFR alpha-4 and the tyrosine kinase Ret form a functional receptor complex for persephin. Curr Biol 8:1019-1022.

Enomoto H, Araki T, Jackman A, Heuckeroth RO, Snider WD, Johnson EMJ, and Milbrandt J (1998). GFR alpha1-deficient mice have deficits in the enteric nervous system and kidneys. Neuron 21:317-324.

Fewtrell MS, Tam PK, Thomson AH, Fitchett M, Currie J, Huson SM, and Mulligan LM (1994). Hirschsprung's disease associated with a deletion of chromosome 10 (q11.2q21.2): A further link with the neurocristopathies? J Med Genet 31: 325-327.

Gershon MD, Chalazonitis A, and Rothman TP (1993). From neural crest to bowel: Development of the enteric nervous system. J Neurobiol 24:199-214.

Goyal RK and Hirano I (1996). The enteric nervous system. N Engl J Med 334:1106-1115.

Heuckeroth RO, Enomoto H, Grider JR, Golden JP, Hanke JA, Jackman A, Molliver DC, Bardgett ME, Snider WD, Johnson EMJ, and Milbrandt J (1999). Gene targeting reveals a critical role for neurturin in the development and maintenance of enteric, sensory, and parasympathetic neurons. Neuron 22:253-263.

Jing S, Wen D, Yu Y, Holst PL, Luo Y, Fang M, Tamir R, Antonio L, Hu Z, Cupples R, Louis JC, Hu S, Altrock BW, and Fox GM (1996). GDNF-induced activation of the ret protein tyrosine kinase is mediated by GDNFR-alpha, a novel receptor for GDNF. Cell 85:1113-1124.

Jing S, Yu Y, Fang M, Hu Z, Holst PL, Boone T, Delaney J, Schultz H, Zhou R, and Fox GM (1997). GFRalpha-2 and GFRalpha-3 are two new receptors for ligands of the GDNF family. J Biol Chem 272:33111-33117.

Klein RD, Sherman D, Ho WH, Stone D, Bennett GL, Moffat B, Vandlen R, Simmons L, Gu Q, Hongo JA, Devaux B, Poulsen K, Armanini M, Nozaki C, Asai N, Goddard A, Phillips H, Henderson CE, Takahashi M, and Rosenthal A (1997). A GPI-linked protein that interacts with Ret to form a candidate neurturin receptor. Nature 387:717-721.

Kobayashi H, O'Briain DS, and Puri P (1994). Nerve growth factor receptor immunostaining suggests an extrinsic origin for hypertrophic nerves in Hirschsprung's disease. Gut 35: 1605-1607.

Le Douarin NM and Teillet MA (1973). The migration of neural crest cells to the wall of the digestive tract in avian embryo. J Embryol Exp Morphol 30:31-48.

Lui VC, Li L, Sham MH, and Tam PK (2001). CDX-1 and CDX-2 are expressed in human colonic mucosa and are down-regulated in patients with Hirschsprung's disease associated enterocolitis. Biochim Biophys Acta 1537:89-100.

Lyonnet S, Bolino A,Pelet A, Abel L, Nihoul-Fekete C, Briard ML, Mok-Siu V, Kaariainen H, Martucciello G, and Lerone M (1993). A gene for Hirschsprung disease maps to the proximal long arm of chromosome 10. Nat Genet 4:346-350.

Martucciello G, Ceccherini I, Lerone M, and Jasonni V (2000). Pathogenesis of Hirschsprung's disease. J Pediatr Surg 35:1017-1025.

Masure S, Cik M, Hoefnagel E, Nosrat CA, Van DLI, Scott R, Van Gompel P, Lesage AS, Verhasselt P, Ibanez CF, and Gordon RD (2000). Mammalian GFRalpha-4, a divergent member of the GFRalpha family of coreceptors for glial cell line-derived neurotrophic factor family ligands, is a receptor for the neurotrophic factor persephin. J Biol Chem 275: 39427-39434.

Mitsuma N, Yamamoto M, Li M, Ito Y, Mitsuma T, Mutoh T, Takahashi M, and Sobue G (1999). Expression of GDNF receptor (RET and GDNFR-alpha) mRNAs in the spinal cord of patients with amyotrophic lateral sclerosis. Brain Res 820:77-85

Moore MW, Klein RD, Farinas I, Sauer H, Armanini M, Phillips $\mathrm{H}$, Reichardt LF, Ryan AM, Carver-Moore K, and Rosenthal A 
(1996). Renal and neuronal abnormalities in mice lacking GDNF. Nature 382:76-79.

Myers SM, Salomon R, Goessling A, Pelet A, Eng C, von Deimling A, Lyonnet S, and Mulligan LM (1999). Investigation of germline GFR alpha-1 mutations in Hirschsprung disease. J Med Genet 36:217-220.

Onochie Cl, Korngut LM, Vanhorne JB, Myers SM, Michaud D, and Mulligan LM (2000). Characterisation of the human GFRalpha-3 locus and investigation of the gene in Hirschsprung disease. J Med Genet 37:669-673.

Paratcha G, Ledda F, Baars L, Coulpier M, Besset V, Anders J, Scott R, and Ibanez CF (2001). Released GFRalpha1 potentiates downstream signaling, neuronal survival, and differentiation via a novel mechanism of recruitment of c-Ret to lipid rafts. Neuron 29:171-184.

Parisi MA and Kapur RP (2000). Genetics of Hirschsprung disease. Curr Opin Pediatr 12:610-617.

Pichel JG, Shen L, Sheng HZ, Granholm AC, Drago J, Grinberg A, Lee EJ, Huang SP, Saarma M, Hoffer BJ, Sariola $H$, and Westphal $H$ (1996). Defects in enteric innervation and kidney development in mice lacking GDNF. Nature 382:7376.

Robertson K, Mason I, and Hall S (1997). Hirschsprung's disease: Genetic mutations in mice and men. Gut 41:436441.

Rossi J, Luukko K, Poteryaev D, Laurikainen A, Sun YF, Laakso T, Eerikainen S, Tuominen R, Lakso M, Rauvala H, Arumae U, Pasternack M, Saarma M, and Airaksinen MS (1999). Retarded growth and deficits in the enteric and parasympathetic nervous system in mice lacking GFR alpha2, a functional neurturin receptor. Neuron 22:243-252.

Salomon R, Attie T, Pelet A, Bidaud C, Eng C, Amiel J, Sarnacki S, Goulet O, Ricour C, Nihoul-Fekete C, Munnich A, and Lyonnet S (1996). Germline mutations of the RET ligand GDNF are not sufficient to cause Hirschsprung disease. Nat Genet 14:345-347.

Sancandi M, Ceccherini I, Costa M, Fava M, Chen B, Wu Y, Hofstra R, Laurie T, Griffths M, Burge D, and Tam PK (2000). Incidence of RET mutations in patients with Hirschsprung's disease. J Pediatr Surg 35:139-142.

Sanchez MP, Silos-Santiago I, Frisen J, He B, Lira SA, and Barbacid M (1996). Renal agenesis and the absence of enteric neurons in mice lacking GDNF. Nature 382:70-73.

Sang Q, Williamson S, and Young HM (1997). Projections of chemically identified myenteric neurons of the small and large intestine of the mouse. J Anat 190(Pt 2):209-222.

Sanicola M, Hession C, Worley D, Carmillo P, Ehrenfels C, Walus L, Robinson S, Jaworski G, Wei H, Tizard R, Whitty A, Pepinsky RB, and Cate RL (1997). Glial cell line-derived neurotrophic factor-dependent RET activation can be mediated by two different cell-surface accessory proteins. Proc Natl Acad Sci USA 94:6238-6243.

Schuchardt A, D'Agati V, Larsson-Blomberg L, Costantini F, and Pachnis V (1994). Defects in the kidney and enteric nervous system of mice lacking the tyrosine kinase receptor Ret. Nature 367:380-383.
Seri M, Yin L, Barone V, Bolino A, Celli I, Bocciardi R, Pasini $B$, Ceccherini I, Lerone $M$, Kristoffersson $U$, Larsson LT, Casasa JM, Cass DT, Abramowicz MJ, Vanderwinden JM, Kravcenkiene I, Baric I, Silengo M, Martucciello G, and Romeo G (1997). Frequency of RET mutations in long- and short-segment Hirschsprung disease. Hum Mutat 9:243-249.

Suvanto P, Wartiovaara K, Lindahl M, Arumae U, Moshnyakov M, Horelli-Kuitunen N, Airaksinen MS, Palotie A, Sariola $H$, and Saarma M (1997). Cloning, mRNA distribution and chromosomal localisation of the gene for glial cell linederived neurotrophic factor receptor beta, a homologue to GDNFR-alpha. Hum Mol Genet 6:1267-1273.

Takahashi M (2001). The GDNF/RET signaling pathway and human diseases. Cytokine Growth Factor Rev 12:361-373.

Tam PK and Boyd GP (1990). Origin, course, and endings of abnormal enteric nerve fibres in Hirschsprung's disease defined by whole-mount immunohistochemistry. J Pediatr Surg 25:457-461.

Treanor JJ, Goodman L, de Sauvage F, Stone DM, Poulsen KT, Beck CD, Gray C, Armanini MP, Pollock RA, Hefti F, Phillips HS, Goddard A, Moore MW, Buj-Bello A, Davies AM, Asai N, Takahashi M, Vandlen R, Henderson $C E$, and Rosenthal A (1996). Characterization of a multicomponent receptor for GDNF. Nature 382:80-83.

Trupp M, Belluardo N, Funakoshi H, and Ibanez CF (1997). Complementary and overlapping expression of glial cell line-derived neurotrophic factor (GDNF), c-ret protooncogene, and GDNF receptor-alpha indicates multiple mechanisms of trophic actions in the adult rat CNS. J Neurosci 17:3554-3567.

Vanhorne JB, Gimm O, Myers SM, Kaushik A, von Deimling A, Eng C, and Mulligan LM (2001). Cloning and characterization of the human GFRA2 locus and investigation of the gene in Hirschsprung disease. Hum Genet 108:409-415.

Wartiovaara K, Salo M, Sainiō K, Rintala R, and Sariola H (1998). Distribution of glial cell line-derived neurotrophic factor mRNA in human colon suggests roles for muscularis mucosae in innervation. J Pediatr Surg 33:1501-1506.

Wilkinson DG and Nieto MA (1993). Detection of messenger RNA by in situ hybridization to tissue sections and whole mounts. Methods Enzymol 225:361-373.

Worley DS, Pisano JM, Choi ED, Walus L, Hession CA, Cate RL, Sanicola M, and Birren SJ (2000). Developmental regulation of GDNF response and receptor expression in the enteric nervous system. Development 127:4383-4393.

Yin L, Barone V, Seri M, Bolino A, Bocciardi R, Ceccherini I, Pasini B, Tocco T, Lerone M, and Cywes S (1994). Heterogeneity and low detection rate of RET mutations in Hirschsprung disease. Eur J Hum Genet 2:272-280.

Yu T, Scully S, Yu Y, Fox GM, Jing S, and Zhou R (1998). Expression of GDNF family receptor components during development: Implications in the mechanisms of interaction. J Neurosci 18:4684-4696. 